\title{
Andrzej Korybski
}

Maria Curie-Skłodowska University in Lublin

ORCiD: 0000-0002-7705-0116

andrzej.korybski@poczta.umcs.lublin.pl

\section{Legal Status of Mediator in Mediation Proceedings in Civil Cases}

\author{
Status prawny mediatora w postępowaniu mediacyjnym \\ w sprawach cywilnych
}

\section{SUMMARY}

In statutory legal cultures, both the introduction of mediation into the legal order and the determination of the legal status of the mediator and his responsibility require legislative action. This is the situation of the Polish legal order. Mediation proceedings in civil cases were introduced into the Polish civil procedure in 2005, while in 2015 the mediation model in civil cases was substantially significantly amended. The mediator's status has also changed as a result of the introduction of a new type of mediator - the so-called permanent mediator, and with a slightly different shaping of the legal liability of mediators. These changes were considered in the article. As a consequence, the reasons for the progressive professionalization of mediation activities have been strengthened.

Keywords: mediation; mediator; legal status; civil case; mediation proceedings; legal liability; professional liability

\section{GENERAL CHARACTERISTICS OF THE SOCIAL AND PROFESSIONAL ROLE OF MEDIATOR}

The issue of legal status of mediator is fairly well represented in legal scholarly literature, especially as regards the position of mediator in common law order ${ }^{1}$. They all follow a certain common model of mediator, with only slight differences

\footnotetext{
1 A fragmentary analysis of the obligations and liability of the mediator is provided in most general studies and textbooks on mediation (cf. Mediation: Principles and Regulation in Compara-
} 
of the mediator's position in particular countries of the Anglo-Saxon legal orders. Civil law culture produced much fewer studies on the mediator's position ${ }^{2}$. The legal status of mediator in statutory law orders is defined by statutory law, sometimes very diverse. This makes it difficult to build the only one model of the legal status of mediator since both the introduction of mediation into legal order and the shaping of the mediator's obligations and rights depends on statutory actions and acts enacted by legislature. Only the statutory framework for mediation allows defining the sphere of rights and obligations of mediator through an agreement between the parties to the dispute and the mediator (the so-called mediation service contract/mediation agreement ${ }^{3}$ ). Any change in legislation on mediation may result in considerable transformations of the mediator's status defined as the entity of his or her rights and obligations in relationships with the parties, the court (if the suit is already pending) and the mediation centre (if the mediator is registered with the list of mediators kept by a given mediation centre).

Obligations of the mediator delineate the scope of his/her legal and professional liability. Thus, a change in the legal regulation of mediation (especially including a change in the sphere of mediator's obligations) modifies the legal status of the mediator. This is the situation we currently face in the Polish legal order. A recent amendment to the Polish law in the field of mediation in civil suits, including in particular the amendment to the Code of Civil Procedure ${ }^{4}$ and the Law on the Justice and Court System ${ }^{5}$, resulted in that the current analysis of the status of mediator in civil cases needs to be modified and supplemented ${ }^{6}$.

tive Perspective, eds. K.J. Hopt, F. Steffek, Oxford 2013, especially pp. 73-92). There are numerous studies available online, which discuss the responsibilities and professional ethics of the mediator in the USA, Australia, New Zealand and other common law countries (referred to as mediation career guides), including the characteristics of the basic types of mediator's liability.

2 In the Anglo-Saxon legal literature, these are usually excerpts from textbooks and monographic studies. There are few papers on this topic (for example, cf. A. Zienkiewicz, Mediator w sprawach cywilnych, „Rejent” 2005, nr 5; W. Broński, M. Dąbrowski, Status prawny mediatora w sprawach cywilnych. Stan obecny i propozycje zmian, „Roczniki Nauk Prawnych” 2014, t. 24, nr 4); A. Bieliński, Mediator w sprawach cywilnych - wybrane zagadnienia regulacji obcych i polskich, http:// arbitraz.laszczuk.pl/_adr/35/Mediator_w_sprawach_cywilnych___wybrane_zagadnienia_regulacji_obcych_i_polskich.pdf [access: 10.12.2017]. See also M. Myślińska, Mediator w polskim porzadku prawnym, Warszawa 2018, passim.

3 Under the Polish binding regulations two kinds of contracts concerning mediation should be distinguished: contract between parties of a given dispute and contract between parties and mediator (who and how should give a mediation service for parties).

4 The Act of 17 November 1964 - Code of Civil Procedure (Journal of Laws, 2016, Item 1822).

5 The Act of 27 July 2001 - Law on the Justice and Court System (Journal of Laws, 2016, Item 2062 as amended).

6 The amendment was made by way of the Act of 10 September 2015 on the amendment of certain acts to support amicable dispute resolution methods (Journal of Laws, 2015, Item 1595). The legislation currently applicable to mediation in civil matters comprise amended provisions of the 
The voluntary nature of mediation and discretion of parties to choose a mediator and decide about the scope of mediation activities is considered a fundamental principle of mediation, including mediation in civil suits. It is a starting point for determination of the essential rights of parties to the dispute regarding the selection of a mediator and setting out his/her rights and obligations ${ }^{7}$. The voluntary nature of mediation means that the parties definitely decide both about undertaking the mediation proceedings and about the rules of doing so and the individual mediator. The voluntary nature of mediation may be restricted by legislature as an exception, by introducing the institution of so-called compulsory mediation, consisting in the obligation to consider mediation as a form of settlement of dispute. Finally, even in this situation, the parties must consent to mediation, the person of mediator and acceptance of the mediation result in the form of a settlement (agreement) between the parties ${ }^{8}$. The admissibility of compulsory mediation must also be based on legislative acts legislation in force.

The starting point for defining the essence and scope of mediator's legal liability is the characteristics of mediator's role in the process of amicable dispute resolution, and more specifically: in the process of amicable resolution of a dispute in civil cases. This is so, because social role ${ }^{9}$ covers established social expectations as to behaviour of specific individuals in particular situations. These behaviours are usually determined by social norms, including applicable legal norms. A crucial part of the normatively defined role of a mediator is the legal status of mediator, understood as a set of rights and obligations of the mediator formed under binding legal acts and legally stated agreements. However, social role cannot be only reduced to norms containing clear-cut expectations of specific conduct in particular situations, addressed to specific individuals as role performers. Personality traits (role model) and cultural conditions for performing a given role, including communication conditions (language and persuasive skills) should also be taken

Code of Civil Procedure and the Law on the System of Common Courts and secondary legislation issued under these Acts.

7 In the Directive 2008/52/EC of the European Parliament and of the Council of 21 May 2008 on certain aspects of mediation in civil and commercial matters, mediation has been defined as a structured process whereby two or more parties to a dispute attempt to reach an agreement on the settlement of their dispute with the assistance of a mediator.

8 More on compulsory mediation: K. Gajda-Roszczynialska, Mediacja obligatoryjna, „Przegląd Prawa Cywilnego" 2012, nr 3, especially pp. 443-446. Cf. also Mediacja. Teoria, normy, praktyka, red. K. Płeszka, J. Czapska, M. Araszkiewicz, M. Pękala, Warszawa 2017, pp. 236-239.

9 For social roles as discussed in the legal scholarly literature, cf. S. Ehrlich, Dynamika norm. Podstawowe zagadnienia wiążacych wzorów zachowania, Warszawa 1994, pp. 223-224. Cf. also G. Skąpska, J. Czapska, M. Kozłowska, Społeczne role prawników (sędziów, prokuratorów, adwokatów), Wrocław 1989; M. Arczewska, Społeczne role sędziów rodzinnych, Warszawa 2009. 
into account ${ }^{10}$. Differences in cultural background are related to the type of legal culture the performer of a given social role operates in; cultural diversity is one of the reasons for the discrepancy between the role and the status of the mediator in statutory legal orders and legal orders based on common law culture. The statutory regulation of rights and obligations of the mediator is crucial for taking a role of mediator in statutory legal order, including the Polish legal order. Other rights and obligations must remain within the constitutional legal order.

The controversial issues of distinguishing the mediator profession requires considering a particular type of social role, namely the professional role. Professional role involves defining (including normative regulation) expectations and patterns for the performance of certain activities in a professional way, that is activities aimed at meeting the needs and aspirations of other social entities, and constituting a source of income and livelihood for the person who performs that professional role (and possibly members of his or her family). The discerning of professional roles is the result of specialization in the production of goods and offering services needed by other entities to meet their needs. Therefore, when identifying a professional role, one should identify the type of goods or services offered by the performer of a given role and the skills necessary to provide this good/service with a proper quality as required on the professional market. The good/service provision is subject to appropriate quotation because the performer of professional role is to be duly paid for the service. The assumption that the social role of mediator is a professional role results from social demand for specific services provided by mediators. The provision of such services needs special requirements and qualifications from the mediator to ensure the quality and effectiveness of the service. A general pattern of the professional role of mediator must also be determined, covering all mediator's rights and obligations, which translates into the legal status of the mediator, including determination of due payment for mediation service.

\section{FACTORS SHAPING THE MEDIATOR'S STATUS IN THE POLISH LEGAL ORDER}

The Polish law currently in force does not explicitly mention all the mediator's tasks and obligations related to the initiation and course of mediation. These responsibilities should be set out in the mediation service contract, and at the same time must fit the general framework delineated by the mediation agreement ${ }^{11}$. When

10 Cf. S. Ehrlich, Wiążace wzory zachowania. Rzecz o wielości systemów norm, Warszawa 1995 , pp. 29-33, 52-60.

11 Cf. Ł. Błaszczak, Charakter prawny umowy o mediację, „ADR. Arbitraż i Mediacja” 2008, nr 1, pp. 25-26. Cf. also W. Broński, M. Dąbrowski, op. cit., p. 12; A. Zienkiewicz, op. cit., passim. 
selecting a mediator from the list of mediators kept by a given mediation centre, it is the mediation centre's responsibility to determine duties and tasks of mediator to the extent not regulated by the applicable legislation. In such a situation, the centre undertakes to define the duties of professional and diligent mediator, and it does so by setting appropriate entry requirements for the list of mediators as well as by establishing appropriate mediator's codes of conduct and professional deontology. However, the parties still have the right to define the content of mediator's contract in a different way. The mediator may choose to withdraw from the agreement if he/she finds the terms proposed by the parties disadvantageous, or where they are inconsistent with the standards and rules adopted in the mediators' organization.

Under the legislation currently in force, the community of mediators is divided into two groups of mediators. The first one is made up of mediators registered with the lists of permanent mediators kept by presidents of relevant regional courts. The second is composed of other mediators, registered with lists maintained by non-governmental organizations or universities, as well as so-called ad hoc mediators freely chosen by the parties from among individuals enjoying full legal capacity and public rights ${ }^{12}$.

Permanent mediator is a mediator who has been listed as a permanent mediator by way of a decision of the president of relevant regional court. Before 1 January 2016, the term 'permanent mediator' used in the literature referred to mediators registered with lists maintained by relevant mediation centres. Although the regulation of the legal status of permanent mediators is not very extensive, it is undoubtedly aimed at the professionalization of mediation activities and, consequently, at strengthening the professional position of the mediator. Currently, the provisions of Articles $157 \mathrm{a}-157 \mathrm{f}$ of the Law on the System of Common Courts determine the qualifications of permanent mediator and procedure for supervision over the performance of mediation activities by him/her. Despite the fact that courts have the responsibility to supervise the activities of permanent mediators, the regulations do not require the State Treasury to assume liability for the activities of a permanent mediator (and other mediators appointed by the court as well). Mediator is also not under obligation to conclude a contract of civil liability for damage caused while conducting mediation. It is a consequence of autonomy of dispute and discretion of parties to choose a mediator. The adoption of a solution involving charging the state with liability for damage caused by the mediator would be reasonable in a situation where the court assumed responsibility for appointing a mediator. However, a permanent mediator appointed by court for a given case must provide an important reason for refusal, unlike other mediators (in particular ad hoc mediators) who may refuse mediating within one week of the receipt of mediation application

12 The Regulation of the Minister of Justice of 20 January 2016 on keeping a list of permanent mediators (Journal of Laws, 2016, Item 122). 
for any reason which even does not need to be disclosed (in this respect, internal regulations of a given mediation centre may tighten the requirements regarding the possible refusal to undertake the role of mediator in a given case).

The legal status of permanent mediator is characterized by increased responsibilities as compared to the legal status of other mediators. The mediator is registered with the list of permanent mediators at his/her request, by way of a decision issued by the president of the district court, and likewise may also be deleted from this list. The president of the regional court has also been equipped with the possibility of verifying the professional activity of permanent mediators and deleting them from the list in a situation where justified reservations were reported to him/her as improper performance of the duties by a permanent mediator. The president of the regional court is assisted by the mediation coordinator. The mediation coordinator must operate in every regional court.

The Act requires that permanent mediators have proper degree of professionalism and no criminal record. It is worth noting here that these additional requirements addressed to permanent mediators have been defined quite generally (as to the necessary mediation expertise and skills). In this situation, mediators registered with the lists of mediators maintained by mediation centres become increasingly important. In their case, there is no problem of the lack of previous documented practice in the field of mediation and completed courses and training improving the expertise in mediation and mediation skills. These mediators are good and verifiable candidates for a permanent mediator.

Three groups of mediator obligations may be distinguished. The first one consists of responsibilities arising from the nature of the legal relationship between the mediator and the parties to mediation. These are primarily the mediator's duties towards the parties to the dispute, but for mediation, upon a court's referral, they can also include duties towards the entity (body) which refers the case to mediation. The second group of obligations consists of those that relate to the mediation centre with which the mediator is registered. These duties are not vested in an ad hoc mediator. They are usually defined in the internal regulations of a particular mediation centre. In a situation where the mediator profession can be defined as a profession not regulated by law, the mediator's responsibilities set out in the internal regulations of a particular centre are aimed at ensuring the necessary professionalism of the mediator in carrying out activities related to mediation proceedings. However, the statutory regulation of the responsibilities of permanent mediators and related liability is still very laconic, and the practice of applying these regulations is still under development. 


\section{RIGHTS AND OBLIGATIONS OF A MEDIATOR IN MEDIATION IN CIVIL SUITS - SELECTED ISSUES}

The amendment to the Code of Civil Procedure and some other acts has introduced changes in the normative regulation of expectations addressed to mediators in civil cases. The applicable legislation does not mention all the mediator's tasks and responsibilities related to the initiation and course of mediation ${ }^{13}$. This means that these responsibilities should be specified in a contract. Another solution is also possible when the mediator is to be selected from the list of mediators maintained by a particular mediation centre. Then the centre undertakes to define the duties of a professional and diligent mediator's conduct, and it does so in a model mediator's agreement by imposing appropriate entry requirements for the list of mediators as well as by establishing appropriate mediator codes of conduct and professional deontology. However, in such a situation, the parties have the right to shape the content of the agreement customized for the given case and the set of rights and duties of the mediator. The mediator may choose to withdraw from agreement if he/she finds the terms proposed by the parties disadvantageous, or where they are inconsistent with the standards and rules adopted in the mediation centre concerned.

The characteristics of the mediator's liability in mediation in civil matters is related to the structural features of mediation and the specificity of mediation in civil matters. It may have a form of civil liability, but also - if we take into account the growing professionalization of mediation activity pursued by mediators associated under mediation centres - a form of sui generis professional liability. If, on the other hand, we consider a mediator to be a professional and we allow the introduction of disciplinary liability of mediators within relevant mediation centres, we can also allow for linking professional (disciplinary) liability with criminal liability ${ }^{14}$.

The statutory regulation of mediation in civil matters allows for the analysis of mediator's civil liability according to the legal basis of mediator's relationship both with the parties and with the court and mediation centre (provided that the mediator is registered with the centre). To determine the liability of the mediator performing mediation activities in civil disputes, it is paramount to regulate the regime and rules for the mediator's liability in civil law. However, this does not preclude an analysis of the mediator's professional liability, including the liability for failure to follow the mediator ethical standards ${ }^{15}$.

13 Likewise: W. Broński, M. Dąbrowski, op. cit., p. 10.

14 Such conclusions are drawn e.g. by N.E. Buzatu, who analyses possible types of offences in the Romanian criminal law related to mediator's failure to keep professional secrets. Cf. N.E. Buzatu, The Responsibility of Mediator, "AGORA International Journal of Juridical Sciences” 2013, No. 4, pp. 11-12.

15 For ethical obligations of a mediator, cf. M. Koszowski, Prawno-etyczne aspekty wykonywania zawodu mediatora (zasady etyki mediatora) z uwzględnieniem standardów europejskich, 
Mediation in civil matters should have a wide range of applications and refer to the structure of a settlement. The parties should have the option to submit to mediation any case that may be concluded with an amicable settlement. This definition of civil matters is broad and covers, apart from civil matters in the strict sense, also family, economic and labour law cases. The group of cases wherein mediation was considered unacceptable due to statutory restrictions (both substantive and procedural), covered cases in the field of social security, cases for recognizing the provisions of the standard contract as prohibited, for establishing paternity or motherhood, marriage annulment, cases for the dissolution of adoption, non-contentious cases such as registration cases, land and mortgage register matters, incapacitation cases, cases for declaring acquisitive prescription or the formal existence of a resolution of the general meeting of a company or for repealing the resolution of the general assembly of the cooperative. It should be added that not only prohibitions expressed directly in law can constitute a formal barrier to reaching a settlement. The court may not approve a settlement that is contrary to the law or rules of social co-existence or is used to circumvent the law, contains contradictions or is incomprehensible. The assessment of whether it is possible to conclude a given civil case by entering into a settlement by the parties, is the responsibility of the court conducting proceedings in a given case.

The wide range of civil cases requires exceptional social competences, knowledge about the complex nature of legal disputes, and interpersonal skills. The requirement of knowledge and competence appropriate to the specificity of a given dispute is addressed also to mediators. The mediator's qualifications do not need to be particularly advanced in certain disputes (such as neighbourly disputes), but in other types of civil disputes (especially family and business-related) these qualifications should be appropriate to the complexity of the subject of the dispute, and these qualifications should be attested with appropriate professional certificates and diplomas and supported by appropriate practice. The task of defining these qualifications and other requirements addressed to mediator lies with the legislative bodies. The general regulation regarding the conditions for the availability of mediation and requirements for the mediation procedure and mediator in civil matters cannot be too detailed so as not to limit the discretion of the parties to choose a mediator, especially in less complex disputes, which do not require advanced knowledge and professional skills.

The Polish legislature distinguished among civil cases those which, due to the legally protected values of social life, should be governed by special legal regulations, including regulations regarding the possibility of applying mediation and reaching an agreement between the parties. These are mediations in family

„Studia Prawno-Ekonomiczne” 2008, nr 77, especially pp. 32-45. See also M. Myślińska, op. cit., pp. 286-266. 
and guardianship cases. The Polish legislature especially recommends mediation for those suits wherein there are real opportunities to sustain a marriage, as well as matters in which the relationship (marriage or informal relationship) terminates with the conclusion by the parties of a clear agreement determining their further relationships aimed at the good of family matters requiring continuation and care for the children. Apart from marital affairs, mediation can also be applied to matters concerning the detailed agreeing upon the manner of exercising parental authority over a common minor child (minor children). In the above cases, the legislature decided that a better solution, in comparison with a top-down decision by the court about the content of the divorce decree, establishment of separation, or determination of the scope of exercising parental authority, is to bring about an agreement between the parties, including giving the parents of a minor child (children) the right to jointly determine the rules for resolving contentious issues. These special regulations are justified by the good of the child as a special, legally protected value. The special character and importance of family disputes requires particular professional qualifications of the mediator, therefore the Polish legislature has decided to establish quite far-reaching requirements for selecting a mediator ${ }^{16}$.

The applicable law sets out the fundamental conditions to be met by a candidate for the mediator in a civil dispute. Such conditions include full capacity to act and full public rights. The scope of rights and obligations of the mediator depends not only on the mediation services contract concluded by the mediator with the parties to the dispute, but also on the mediation role played by the mediator ( $a d$ hoc mediator, mediator selected from the mediation centre, permanent mediator). Provisions of the Code of Civil Procedure stipulate that an active judge cannot perform the role of mediator. However, these rules constitute a loophole for inactive judges wanting to mediate. Such a solution does not violate the principle of impartiality of the mediator, and at the same time takes into account the requirements of legal professionalism in the examination of the substance of the dispute. The applicable legislation does not provide a basis to prevent other people working in courts or related to justice administration (like judicial clerks, court referendaries, court clerks, lay judges) from performing the role of mediator. It seems that with regard to mediation, these people must not be appointed mediators on the court's initiative, as they may be involved in a given dispute in the future when mediation fails ${ }^{17}$. Worthy to notice, however, that some civil law scholars allow recognising the result

${ }^{16}$ On the specific nature of mediation and the position of the mediator in mediation in family matters cf. e.g. A. Gójska, V. Huryn, Mediacja w rozwiązywaniu konfliktów rodzinnych, Warszawa 2007; M. Kwiatkowska, Instytucja mediacji w sprawach rodzinnych, „Zeszyty Naukowe Instytutu Administracji AJD” 2012, nr 2(6), pp. 95-118; M. Kaźmierczak, J. Kaźmierczak, Mediacja rodzinna, Warszawa 2015.

17 Likewise: P. Telenga, [in:] Kodeks postępowania cywilnego. Komentarz, red. A. Jakubecki, t. 1, Warszawa 2017, p. 336. 
of mediation as effective also when the settlement was agreed upon before a person without specific professional qualifications to mediate in civil matters where such qualifications are required. This position is supported by the fundamental principles of autonomy of the dispute and the voluntary nature of mediation, as well as the supremacy of the will of the parties in appointing a mediator. However, general requirements regarding the mediator should be met, in particular, the requirement of full legal capacity to act; it is indispensable for the effective performance of many activities during mediation proceedings, including the preparation of a report on the course of the mediation proceedings.

Mediator should be impartial when conducting mediation. However, contrary to the position prevailing among scholars, this impartiality also includes neutrality of the mediator understood as abstaining from relations that would raise a suspicion of partiality (e.g. kinship, friendly relationships, relation of subordination, etc.). Legal acts do not regulate the question of recusal of a mediator for the lack of impartiality (neutrality), because due to the principle of voluntary nature of mediation, each party has the option to refuse to consent to such a mediator. There is a question of how to do it when the suspicion of lack of neutrality or bias arises after both parties consented as to the selection of the mediator. It seems to be valid that the violation of the principle of impartiality by a permanent mediator, including that involving the concealment of circumstances raising doubts as to his/her impartiality, is the condition for finding improper performance of duties within the meaning of Article $157 \mathrm{c} \S 1$ Item 5 of the Law on the System of Common Courts, about which the court should ex officio notify the competent president of the court.

The course and results of mediation proceedings are not open to third parties to the participants in mediation proceedings (including party family members, party representatives, experts, etc.). Such legal regulation of confidentiality of mediation is justified by its voluntary nature. However, the parties may mutually agree to allow such persons to participate in the mediation, and this should be done in consultation with the mediator. It should be assumed that if the parties introduce third parties to mediation without such an agreement, this may form a basis for the mediator to give up the mediation. This regulation is a consequence of the principle of confidentiality of mediation. Therefore, it should be stated that a mediator who violated the principle of confidentiality causing damage to the parties will bear compensatory liability based on Article 471 of the Civil Code ${ }^{18}$.

The source of the contractual legal relationship between the mediator and the parties is the mediation services contract/mediator's agreement. In the civil law doctrine, such a contract is usually treated as an unnamed contract, to which, pur-

18 Likewise: M. Pazdan, Prawa i obowiazki oraz odpowiedzialność mediatora, [in:] Odpowiedzialność cywilna, red. M. Pyziak-Szafnicka, Kraków 2004, as cited in Kodeks postępowania cywilnego..., p. 338. 
suant to Article 750 of the Civil Code, the provisions on contract job agreement (umowa zlecenia) ${ }^{19}$ should be applied. If a case is referred to mediation by the court, it should be considered that also the legal act of the parties (their consent), not the court's decision, is the legal event that establishes such a contractual relationship. In this situation, however, it should be stated that discretion of the parties with regard to determining the content of such a contract by the parties is limited by the content of the court's decision as to the duration of the mediation. The parties are not bound by the decision of the court as to the choice of a mediator. The parties' consent to mediation should be explicit, not implied ${ }^{20}$.

The court may appoint both an ad hoc mediator from the list of mediation centre or a permanent mediator. But the court does it only when the parties themselves have not selected a mediator. If the parties have not chosen a mediator, and at least one of them does not consent to the mediator appointed by the court, that party should request that the mediator be recused, and apply for the appointment of another one or to withdraw from the mediation. To avoid sanctions under Article $1103 \S 2$ of the Code of Civil Procedure, the party should specify the reason for the lack of consent resulting from the objections about the mediator. Also, a joint application of the parties to change the mediator should be allowed at any time of the period set by the court for mediation proceedings. The parties wishing to change the mediator should, within a week, notify the court that they have chosen another mediator. Assuming that the legal relationship between the mediator and the parties is based on a contract, it should be considered that the parties' right to choose a mediator also results from the fact that the parties are not obliged to enter into a contract with a mediator appointed by the court. It cannot be excluded that the parties will choose another mediator during mediation and with the consent of the current mediator will terminate the contract and entrust the new mediator to conduct the mediation. Then a not quite regulated issue arises as to mutual settlements between the current mediator and the parties and the liability of the previous mediator. In such a situation, it should be assumed that the mediator's contract may contain terms of withdrawal, including on the compensation for early termination (Article 396 of the Civil Code).

Under the current legislation, the mediator has the right and obligation to read through the files of the case. The mediator's communication with the parties does not apply the principle of official delivery, but due to his/her responsibility, the mediator should have confirmation of receipt of the appropriate material. Once the mediator's contract is concluded, the mediator should promptly proceed to mediation activities, including agreeing with the parties the date and place of the

19 This position is prevailing among scholars. Cf. Kodeks postepowania cywilnego..., p. 339.

${ }^{20}$ Likewise: ibidem, p. 343. Cf. also J. Jodłowski, Z. Resich, J. Lapierre, T. Misiuk-Jodłowska, K. Weitz, Postępowanie cywilne, Warszawa 2014, p. 322. 
mediation session. The inability to agree upon this results essentially in the refusal of mediation.

The formal requirements of the application for mediation are similar to the requirements for the statement of claim. Thus, the objective and subjective limits of mediation are determined. However, this application does not constitute a pleading in the formal sense. If the application lacks essential elements, the mediator is obliged to request the parties to complete the application. This is one of the few examples of introducing certain formal requirements to mediation proceedings, caused by concern for the legal interest of the parties when a settlement is reached. Therefore, it seems that refusal by the mediator to conduct mediation, only motivated by gaps or defects of the application, should not take place ${ }^{21}$.

The parties to the mediation agreement may themselves define the obligations and tasks of the mediator; there are also model mediation activities developed in particular mediation centres ${ }^{22}$. These models may be accepted in the situation a mediator is chosen from the list of mediators maintained by a given mediation centre. Then the centre undertakes to define the professional and diligent conduct of a mediator, and implements it by organizing training courses and improving the knowledge and skills of mediators associated within a given centre. If the parties choose an ad hoc mediator or do not accept a mediator from the list kept by a particular mediation centre, the responsibility to define the tasks and obligations of the mediator is vested in the parties themselves, which should do so by agreeing upon appropriate contractual provisions.

The characteristics of mediator's powers is based basically on the regulation contained in the provisions of the Code of Civil Procedure, Law on the System of Common Courts and the Act of 27 July 2005 on court costs ${ }^{23}$, according to which the court determines and grants the mediator a remuneration for conducting mediation initiated on the court's initiative. Under the legislation effective until 1 January 2016, the remuneration of the mediator was not deemed an expense within the meaning of the Act on court costs in civil cases and was agreed and paid by the parties without the participation of the court, regardless of whether the case was mediated at the will of the parties, or at the request of the court, accepted by the parties. This had its further legal consequences in terms of tax regulations, which were basically much less favourable for mediators as compared to the legislation in force from 1 January 2016. Currently, the accounting of mediation costs for court costs allows the parties to apply to the court for being exempt from these costs. Therefore, it is a much better solution for the parties to the dispute. It also changes the financial position of the mediator as regards his/her income in the perspective

\footnotetext{
21 According to Kodeks postępowania cywilnego..., pp. 341-342.

22 In more detail: W. Broński, M. Dąbrowski, op. cit., passim.

23 Journal of Laws, 2018, Item 300.
} 
of tax law. However, it should be noted that it is still possible for the mediator to enter into such an agreement on the remuneration with the parties, and that in this situation he or she will be able to be paid by the parties for mediation activities, as well as reimbursement of costs incurred for mediation purposes. The principle that the remuneration of the mediator and the reimbursement of expenses incurred by him/her are borne by the parties to the proceedings continues to apply. It seems that in the further phase of improving the legal provisions on mediation, it would be worth considering introducing partial regulations transferring a reasonable part of the costs related to mediator's persuading the parties to mediation and preparing a mediation proceeding (and thus a kind of 'mediation assistance' for the parties) to the government, following the solutions concerning free-of-charge legal assistance. The state should be interested, due to the legal and international and EU law obligations assumed, as well as the principle expressed in Article 10 of the Code of Civil Procedure on amicable settlement of civil disputes.

Detailed solutions regarding the amount of remuneration for the mediator and his/her expenses when the remuneration and reimbursement are determined by the court are set out in the secondary legislation issued under the Act on court costs in civil cases ${ }^{24}$. However, the reimbursement of expenses incurred by the mediator to initiate and conduct the mediation proceedings should only cover the necessary and reasonable expenses. The liability of the parties towards the mediator (including due to the mediator's claim for remuneration) is based on the concept of joint and several liability. Under the current legislation, the costs of mediation proceedings are not included in court costs, but in the cases specified in Article 98/1 $\S 1$ and 2 of the Code of Civil Procedure they constitute the costs of the trial necessary for the purposeful pursuing one's rights and defence. This is a crucial regulation as the mediator is not entitled to a claim to the State Treasury for the payment of remuneration not paid by the parties, and the mediators must pursue their claims against the parties.

An important rule is the possibility of a complaint submitted by the parties or a mediator to a higher court on the decision of the court of first instance regarding the setting of the amount of remuneration for the mediator and reimbursement of costs incurred by the mediator. It will be interesting to keep track of the judicial practice in these matters, because the contents covered by such a complaint may be in conflict with one of the fundamental principles of mediation, namely the principle of confidentiality. The mediator, parties and other people involved in the mediation proceedings are obliged to keep confidential the facts they learned about during the mediation. Only the parties may release the mediator and other persons involved in

24 These issues are governed by the Regulation of the Minister of Justice of 20 June 2016 on remuneration and reimbursement of expenses incurred by the mediator in civil proceedings (Journal of Laws, 2016, Item 921). 
these proceedings from this obligation. However, owing to this solution, the court has been equipped with a real possibility of access to the data and information the parties to the dispute might want to keep for themselves. Without such information, it could not be possible for the court to review how the mediator performs his/her duties related to the effective conduct of mediation, including rational justification for the costs incurred.

\section{CONCLUSIONS}

Under the current legislation on mediation in civil cases, the status of mediator is a result of a compromise between the expectations of various social groups interested in amicable settlement of civil disputes ${ }^{25}$. It is debatable whether these expectations from at least three groups of entities interested in mediation (i.e. the parties to the dispute as clients of mediation services, mediator professional communities, in particular, mediation centres, bringing together most mediators and, finally, state authorities involved in mediation processes, in particular courts) are already socially clearly crystallized and fairly established. However, it should be clearly stated that the normative model of the role of a professional mediator is not a model that could be wholly legally defined. The statutory solutions form a framework for the legal possibilities of mediation. They concern the scope and rules of mediation proceedings. However, they do not determine in detail the choice and sequence of all professional activities of the mediator, they only set out the key issues and the rules and duties of the mediator in mediation proceedings. Therefore, they concern the fundamental requirements related to ensuring that the mediation is voluntary, impartiality and professionalism of the mediator, and confidentiality of the mediation. The other mediator's duties related to the preparation and conduct of mediation is in fact left to the parties and the mediator himself/herself. The expectations of the parties towards mediation and the mediator are therefore a factor that gives content to the general framework of the mediator's professional role. Obviously, the essence and specificity of a given civil case affects the expectations of the parties formulated towards the mediator and finally expressed in the mediator's agreement.

In the light of the findings above, an important requirement imposed on the mediator is his/her appropriate knowledge of the applicable legislation as well as possibilities and conditions for the use of appropriate legal instruments to reach a settlement in the dispute. It is necessary for the mediator to have basic legal knowledge regarding the legal regulation of the resolution of certain types of cases, as well as actual skills to mediate in a dispute in order to achieve a lasting settle-

${ }^{25}$ In more detail: M. Myślińska, op. cit., pp. 71-152. Cf. also A. Kalisz, Mediacja jako forma dialogu w stosowaniu prawa, Warszawa 2016, pp. 25-41. 
ment between the parties. One can imagine a mediator who is able to acquire and use legal knowledge in order to resolve disputes in various areas and branches of applicable law. It seems, however, that for the whole community of mediators who treat mediation activity as a profession, the professional specialization according to the nature of cases under mediation is inevitable and reasonable. For professional mediators, it is reasonable, and in the long run unavoidable, to specialize in matters of a specific type, including in resolving civil cases as cases of disputes arising under broadly understood civil law. Then one can distinguish some special requirements addressed to mediators in certain socially significant types of civil cases, such as cases in family, business, consumer etc. matters.

The entirety of social expectations that make up the above-mentioned standard of mediator's conduct (and thus the norms setting out the rights and obligations of the mediator in terms of the mediator's professional role) determines the social status of the mediator. It comprises the legal status of the mediator, including his/ her rights and obligations under applicable law. On the other hand, distinguishing the duties attributed to the mediator raises the question of the mediator's liability. The mediator's legal liability arises where the mediator failed to perform his or her duties to act or to abstain from action. These duties are largely formed by the type of contractual relationship between the mediator and the parties to the dispute. The voluntary nature of mediation means that the parties definitely decide both about undertaking the mediation proceedings and about the rules of doing so and the individual mediator. The parties themselves may decide on the organisational framework of this procedure under the national civil law. However, the national legislature may regulate in the form of an Act the key parts of this procedure, and even use the construct of obligatory mediation. The Polish legislature have not introduced the institution of obligatory mediation, although the obligatory nature of the participation of the parties in the so-called information proceedings, oriented at the examination by the parties of the possibilities of amicable settlement of the case, should be mentioned in the context of the amendment to the Code of Civil Procedure.

The determination of the legal character of the mediator's contract is widely disputed by scholars of law. The provisions of law are lacking any specific formal requirements regarding both the very conclusion of the contract and its legal form. Therefore, it should be assumed that the mediation agreement is a bilateral legal act of a mutual obligation nature, resulting in substantive legal effects, as specified by the parties, in the sphere of the rights and obligations of both the parties to the dispute and the mediator. The position which considers the mediator's contract as an unnamed contract seems to be appropriate; however, it is possible to accept at least partial validity of this contract as a named contract, but not governed by the provisions of the Civil Code (assuming that at least some of essential provisions of a mediator's contract concluded in relation to pending civil proceedings are regulated by the provisions of the Code of Civil Procedure). From the point of view 
of the structure of such a contract, it may be a separate agreement or an agreement linked with the mediation agreement or - by way of the so-called a mediation clause - with another, broader agreement between the parties.

For mediation under an explicit mediator's contract, it is clear that the mediator's liability is contractual because it results from the content of the contractual relationship forming its base. In the other two situations, it is not so easy to determine that the mediator's liability is contractual. In these situations, mediation proceedings are commenced on the condition of the consent to mediation by both parties (when the case is referred to mediation by the court) or by the other party (in the situation when the first party files the application for mediation). As a consequence, views taken in the literature assume that in both situations the contract is concluded between the parties to the dispute and the mediator, but the contract is implied, resulting from the actions taken by one or both parties to the dispute (i.e. per facta concludentia) ${ }^{26}$.

Regarding the controversial postulate of statutory regulation of the profession of mediator as a regulated profession, proposed for at least a dozen or so years by the mediator community, it should be noted that the postulate was partially implemented by introducing a regulation on permanent mediators into Section IV of the Law on the System of Common Courts, i.e. a section concerning groups of professions, operating in common courts, which are not judges (such as court referendaries, probation officers, court administrative personnel). However, the statutory regulation of the legal status of the mediator covers only permanent mediators and is partial in comparison with the statutory regulation of other professions related to the justice system and regulated professions. Therefore, neither does it cover the entire community of mediators nor regulates many important issues, such as self-government of mediators and competences of self-government bodies, comprehensive regulation of entry requirements for the professional group of mediators, and the rights and obligations of the mediator (including professional ethics). It can be said then, that even thought there has already been a sufficiently legally defined profession of mediator, its regulation (also statutory in part) cannot be compared with the statutory regulation of the so-called regulated professions ${ }^{27}$. The legal status of this profession is regulated only in a fragmentary manner, and

26 Cf. R. Cebula, Mediacja w polskim prawie cywilnym, „Mediator” 2005, nr 34, p. 28; J. Kuźmicka-Sulikowska, Podstawa prawna odpowiedzialności cywilnej mediatora, „ADR. Arbitraż i Mediacja” 2008, nr 3, pp. 78-79.

27 The characteristics of the professions of mediator and court mediator are set out in the Polish legal order in an annex to the Regulation of the Minister of Labour and Social Policy on the classification of professions and specializations for the needs of the labour market (Journal of Laws, 2014, Item 1145; Journal of Laws, 2016, Item 1876). Cf. also W. Broński, P. Sławicki, Mediator - czy potrzebna specjalna ustawa, www.rp.pl/artykul/1093170-Bronski-Slawicki-o-mediacji-czy-potrzebna-specjalna-ustawa.html [access: 27.04.2017]. 
there are no grounds to state that each mediator performs his or her activities as a professional due to the legally undefined status of the ad hoc mediator.

Two solutions regarding the statutory regulation of the mediator profession have developed in European countries ${ }^{28}$. In the first model (i.a. in Poland, Belgium, Denmark, France, the Netherlands, Portugal and Great Britain), the profession of mediator and the mediation proceedings are subject to fragmentary regulation in various statutory acts, including in codes of court proceedings. In the second model, the regulation of the profession of mediator and mediation takes place in one act as a kind of constitution for the profession of mediator (e.g. in Austria, Bulgaria, Estonia or Finland). This does not preclude regulation of certain issues relevant to the profession of mediator and mediation in other statutory acts, but the lex generalis - lex specialis relationship takes place between the act fundamental for mediation and other acts. However, it should be noted that also in this second model there is no separate statutory regulation regarding the profession of mediator alone. A comparative legal analysis allows us to formulate the thesis about the sufficiency of dispersed statutory regulation of both the mediator profession and mediation proceedings (or rather mediation procedures, because they are differentiated, according to the nature and scope of legal regulation, into mediation in civil law, criminal law and public/administrative law).

Despite the essentially positive evaluation of the current Polish statutory provisions regarding mediation and the mediator profession, certain issues concerning the mediator profession need to be further developed or improved. This especially applies to the introduction of a coherent (and perhaps unified within the scale of the national legal order) mediator accreditation system, establishing the same or similar requirements for all mediators wanting to specialize in a specific type of litigation. It is also worth considering establishing a coherent training system and other forms of improving qualifications in mediation. Undoubtedly, the introduction of such solutions would entail further statutory changes in the legal status of the mediator, and consequently also the redefinition of mediator's professional liability, including the mediator's liability in civil matters.

Last but not least, the issue of mediator's insurance against any damage resulting from the mediation service must be addressed ${ }^{29}$. It seems that entering into such

${ }^{28}$ For a representative comparative material on this issue, see: K.J. Hopt, F. Steffek (eds.), op. cit., passim.

29 In the Western literature on mediation and the profession of mediator, the issue of civil liability insurance is considered one of the basic issues determining further professionalization of the occupation of mediator. Cf. B.I. Kogan, Mediator Liability and Mediator Liability Insurance, www. rimediators.org/yahoo-siteadmin/assets/docs/Mediator_Liability_Insurance.21280717.pdf [access: 9.03.2018]; R.A. Badgley, Mediator Liability Claims: A Survey of Recent Developments, www. lockelord.com/ /media/Files/Newsandevents/publications/2013/05/Mediator\%Liability [access: 9.03.2018]. 
insurance contracts with appropriate insurers by ad hoc mediators is unlikely on a wider social scale. However, the problem here is to estimate the possible risk and to develop relevant models for the insurance contract. Anyway, it does not seem that insurance companies are interested in offering such insurance services on a wider basis. The issue of insurance of mediators listed in mediation centres is another story. First of all, mediation centres themselves may require liability insurance as a requirement of membership in a given centre. Secondly, insurance companies are interested in providing such insurance services to mediators brought together in a particular mediation centre due to the so-called insurance economies of scale. This is also the practice of largest mediation centres in Poland.

Another issue is the compulsory mediator's civil liability insurance. Indeed, such a postulate is sometimes put forward, but usually it is about introducing a statutory duty of mediators to insure their activities against civil liability, similar to the insurance requirement imposed on the representatives of many liberal professions as so-called regulated professions (such as attorneys or legal counsels). It seems that the introduction of compulsory civil liability insurance as the obligation of mediators would require full professionalization of the occupation of mediator, hence giving up the institution of ad hoc mediators. This would entail the introduction of obligatory membership of mediators in some nationwide mediator organization of self-government nature. This would require statutory regulation of the mediators' self-government and consideration about how such a solution would apply to the principles of voluntary mediation and the discretion of parties to choose a mediator. For this reason, the postulate of shaping the profession of mediator as a profession regulated by statutory acts and having its own professional self-government seems to be unlikely to be implemented, at least in the near future. Nonetheless, it cannot be completely ignored, since it is increasingly put forward by the communities of mediators in particular Member States of the European Union.

\section{REFERENCES}

Arczewska M., Spoleczne role sędziów rodzinnych, Warszawa 2009.

Badgley R.A., Mediator Liability Claims: A Survey of Recent Developments, www.lockelord.com/ / media/Files/Newsandevents/publications/2013/05/Mediator\%Liability [access: 9.03.2018].

Bieliński A., Mediator w sprawach cywilnych - wybrane zagadnienia regulacji obcych i polskich, http://arbitraz.laszczuk.pl/_adr/35/Mediator_w_sprawach_cywilnych___wybrane_zagadnienia_regulacji_obcych_i_polskich.pdf [access: 10.12.2017].

Błaszczak Ł., Charakter prawny umowy o mediacje, „ADR. Arbitraż i Mediacja” 2008, nr 1.

Broński W., Dąbrowski M., Status prawny mediatora w sprawach cywilnych. Stan obecny i propozycje zmian, „Roczniki Nauk Prawnych” 2014, t. 24, nr 4.

Broński W., Sławicki P., Mediator - czy potrzebna specjalna ustawa, www.rp.pl/artykul/1093170-Bronski-Slawicki-o-mediacji-czy-potrzebna-specjalna-ustawa.html [access: 27.04.2017]. 
Buzatu N.E., The Responsibility of Mediator, “AGORA International Journal of Juridical Sciences" 2013, No. 4.

Cebula R., Mediacja w polskim prawie cywilnym, „Mediator” 2005, nr 34.

Directive 2008/52/EC of the European Parliament and of the Council of 21 May 2008 on certain aspects of mediation in civil and commercial matters.

Ehrlich S., Dynamika norm. Podstawowe zagadnienia wiążacych wzorów zachowania, Warszawa 1994.

Ehrlich S., Wiążace wzory zachowania. Rzecz o wielości systemów norm, Warszawa 1995.

Gajda-Roszczynialska K., Mediacja obligatoryjna, „Przegląd Prawa Cywilnego” 2012, nr 3.

Gójska A., Huryn V., Mediacja w rozwiązywaniu konfliktów rodzinnych, Warszawa 2007.

Jodłowski J., Resich Z., Lapierre J., Misiuk-Jodłowska T., Weitz K., Postępowanie cywilne, Warszawa 2014.

Kalisz A., Mediacja jako forma dialogu w stosowaniu prawa, Warszawa 2016.

Kaźmierczak M., Kaźmierczak J., Mediacja rodzinna, Warszawa 2015.

Kodeks postępowania cywilnego. Komentarz, red. A. Jakubecki, t. 1, Warszawa 2017.

Kogan B.I., Mediator Liability and Mediator Liability Insurance, www.rimediators.org/yahoo-siteadmin/assets/docs/Mediator_Liability_Insurance.21280717.pdf [access: 9.03.2018].

Koszowski M., Prawno-etyczne aspekty wykonywania zawodu mediatora (zasady etyki mediatora) z uwzględnieniem standardów europejskich, „Studia Prawno-Ekonomiczne” 2008, nr 77.

Kuźmicka-Sulikowska J., Podstawa prawna odpowiedzialności cywilnej mediatora, „ADR. Arbitraż i Mediacja” 2008, nr 3.

Kwiatkowska M., Instytucja mediacji w sprawach rodzinnych, „Zeszyty Naukowe Instytutu Administracji AJD” 2012, nr 2(6).

Mediacja. Teoria, normy, praktyka, red. K. Płeszka, J. Czapska, M. Araszkiewicz, M. Pękala, Warszawa 2017.

Mediation: Principles and Regulation in Comparative Perspective, eds. K.J. Hopt, F. Steffek, Oxford 2013.

Myślińska M., Mediator w polskim porządku prawnym, Warszawa 2018.

Pazdan M., Prawa i obowiazki oraz odpowiedzialność mediatora, [in:] Odpowiedzialność cywilna, red. M. Pyziak-Szafnicka, Kraków 2004.

Skąpska G., Czapska J., Kozłowska M., Społeczne role prawników (sędziów, prokuratorów, adwokatów), Wrocław 1989.

Telenga P., [in:] Kodeks postepowania cywilnego. Komentarz, red. A. Jakubecki, t. 1, Warszawa 2017. The Act of 17 November 1964 - Code of Civil Procedure (Journal of Laws, 2016, Item 1822).

The Act of 27 July 2001 - Law on the Justice and Court System (Journal of Laws, 2016, Item 2062 as amended).

The Act of 27 July 2005 on court costs (Journal of Laws, 2018, Item 300).

The Act of 10 September 2015 on the amendment of certain acts to support amicable dispute resolution methods (Journal of Laws, 2015, Item 1595).

The Regulation of the Minister of Justice of 20 January 2016 on keeping a list of permanent mediators (Journal of Laws, 2016, Item 122).

The Regulation of the Minister of Justice of 20 June 2016 on remuneration and reimbursement of expenses incurred by the mediator in civil proceedings (Journal of Laws, 2016, Item 921).

The Regulation of the Minister of Labour and Social Policy on the classification of professions and specializations for the needs of the labour market (Journal of Laws, 2014, Item 1145; Journal of Laws, 2016, Item 1876).

Zienkiewicz A., Mediator w sprawach cywilnych, „Rejent” 2005, nr 5. 
Pobrane z czasopisma Studia Iuridica Lublinensia http://studiaiuridica.umes.pl Data: 26/04/2023 02:53:55

\section{STRESZCZENIE}

W kulturze prawa stanowionego zarówno wprowadzenie postępowania mediacyjnego do porządku prawnego, jak też określenie statusu prawnego mediatora i jego odpowiedzialności wymaga działań ustawodawczych. Z taką sytuacją mamy do czynienia w polskim porządku prawnym. Postępowanie mediacyjne w sprawach cywilnych zostało wprowadzone do prawa cywilnego w $2005 \mathrm{r}$., zaś w 2015 r. model mediacji w sprawach cywilnych został dość istotnie znowelizowany. Zmianom uległ też status mediatora w związku z wprowadzeniem nowego typu mediatora - tzw. stałego mediatora, a także z nieco innym ukształtowaniem odpowiedzialności prawnej mediatorów. Zmiany te zostały rozważone w artykule. W ich konsekwencji wzmocnione zostały przesłanki postępującej profesjonalizacji czynności mediacyjnych.

Słowa kluczowe: mediacja; mediator; status prawny; sprawa cywilna; postępowanie mediacyjne; odpowiedzialność prawna; odpowiedzialność zawodowa 